\title{
DHATRI LOHA IN THE MANAGEMENT OF IRON DEFICIENCY ANEMIA
}

\author{
Ragamala $\mathrm{KC}^{1^{*}}$, Shailaja $\mathrm{U}^{2}$, Prasanna Kumar T ${ }^{3}$
}

\begin{abstract}
$\underline{\text { Abstract }}$
Iron deficiency anemia is currently the most widespread micronutrient deficiency affecting nearly 1.5 billion people globally i.e. around $1 / 3$ of the whole population. About $70 \%$ of Indians are found to be anemic out of which, $95 \%$ of anemia is due to iron deficiency. Infants, preschool children and adolescents are at greatest risk of developing iron deficiency and its resultant anemia. It is mostly seen in rural areas and in communities of low socioeconomic group. Because of this reason IDA was selected for this study to assess the efficacy of Dhatriloha. So to evaluate the effect of Dhatriloha in the management of Iron deficiency anemia in children aged between 1-6years the present study has been taken up. 30 patients, from Kaumarabhritya OPD and IPD of SDMCA \& H, Hassan, fulfilling the inclusion and exclusion criteria were selected in to study. Dhatriloha was administered in a dose of $250 \mathrm{mg}$ twice daily for a period of 60 days. The cases were recorded according to the case performa and observations were recorded. Symptoms were scored and statistically analyzed for any change before and after the study. In the group statistically highly significant change $(\mathrm{P}=$ $<0.001)$ was observed in the signs and symptoms of IDA. There was a statistically highly significant response in hemoglobin concentration in the group $(\mathrm{P}=<0.001)$.
\end{abstract}

Keywords: Iron deficiency anemia, Panduroga, Dhatriloha.

\section{Introduction:}

Anemia is defined as a reduction of the red blood cell volume or hemoglobin concentration and hematocrit below the range of values occurring in healthy persons.Anemia resulting from lack of sufficient iron for synthesis of hemoglobin is the most common hematological disease of infancy and childhood and this is called as Iron Deficiency Anemia (IDA).

Iron deficiency anemia is currently the most widespread micronutrient deficiency and affects nearly 1.5 billion people globally. Presently available data has shown that one-third of world's population suffers from iron deficiency anemia and of which 90 percent lives in the third world countries. About $70 \%$ of Indians are found to be anemic. $74 \%$ of children between the age group of 6 to 35 months are anemic.
The iron released from the senescent red cells during the first 8 to 12 weeks of life (a period of quiescent erythropoiesis) is stored in the body and helps maintain erythropoiesis up to 4 to 6 months in a normal term infant and up to 2 to 3 months in the low birth weight infant. Normal infants at birth have about $75 \mathrm{mg}$ of iron per $\mathrm{kg}$ body weight, two-thirds of which is present in red blood cells. Infants and children should continue to absorb 0.8 to $1.0 \mathrm{mg}$ of iron daily to reach the adult body stores of 4 to 5 grams. Iron stores are highest during infancy during period of rapid growth. Iron is also required more in first few years of life and during adolescence.

The dietary iron comes from two sources: Heme and non-heme, later being the major source of iron in diet and is found in varying degrees in all foods of plant origin. Heme iron is present in meat, fish and poultry, but the intake of these

1 MD Scholar, 2. Professor \& HOD, Dept of P.G Studies in Kaumarabhritya, S.D.M. College of Ayurveda \& Hospital, Hassan - 573201, 3.Assistant professor, Dept. of PG studies in Rasashastra, JSS Ayurveda Medical College, Mysore-570015

*.Corresponding author: MD Scholar, Dept of P.G Studies in Kaumarabhritya, S.D.M. College of Ayurveda \& Hospital, Hassan - 573201, E.mail: drprasannakumart@gmail.com 
products is generally low. Heme iron is better absorbed (35\%) than non-heme iron $(\sim 5 \%)$ and is not influenced by dietary factors.

Additional sources of iron in the diet include the exogenous sources originating from soil dust, water and cooking of foods in iron pots but the bioavailability of iron is less and the contribution insignificant. Good sources of iron in the diet include pulses, dals, green leafy vegetable, bajra, dates, nuts, jaggery, meat and fish. Administration of $50 \mathrm{mg}$ of vitamin $\mathrm{C}$ increases iron absorption by two-fold.

Iron stores in the body such as hemosiderin in the liver and bone marrow are diminished. Thereafter, serum ferritin level falls to less than $10 \mathrm{ng} / \mathrm{ml}$ followed by a decrese in the level of serum iron and increase in the total iron-binding capacity. Free erythrocyte porphyrin level rises. Microcytic hypochromic anemia occurs and the activity of iron-containing enzymes diminishes.

Causes of Iron Deficiency Anemia include decreased Iron Stores (Preterm, small-for-dates, twins), decreased intake / assimilation (Delayed weaning, malnutrition, Iron poor diet etc, Increased Losses (GI bleeding etc) and Increased Demands (Prematurity, LBW etc)

Management includes Eradication of underlying cause, Correction of Anemia by oral iron therapy and in severe cases parenteral iron therapy.

The present study is planned to supplement the iron to the patients of IDA with the Ayurvedic Medicine which contains iron as one of the ingredient along with other herbal ingredients. So for the study Dhatriloha, an iron containing preparation is selected for the study.

\section{Aims and objectives of the study:}

To study the effect of Dhatriloha in the management of Iron deficiency Anemia in Children below 6 years of age.
Materials and Methods:

Source of data:

Diagnosed cases of Panduroga were included from Kaumarabhritya OPD and IPD of S.D.M.C.A and Hospital, Hassan.

\section{Methods of collection of data:}

Thirty patients who were fulfilling the diagnosis and inclusion criteria were selected for the study.

\section{Selection of patients and method of study:}

By following the inclusion and exclusion criteria, 30 children presenting characteristics features of Panduroga were randomly included in the present study. Such selected children were examined thoroughly and record was made on the assessment criteria as per the case sheet specially prepared for the purpose.

\section{Inclusion criteria:}

- Patients presenting with classical signs and symptoms of IDA

- Children with hemoglobin percentage between 8 to $12 \mathrm{gm} / \mathrm{dl}$

- Patients of both sex between the age group of 1 to 6 years

\section{Exclusion criteria:}

- Patients with severe Anemia due to systemic disorders.

- Hemorrhagic diathesis like Hemophilia, ITP, Vit. K deficiency etc.

- Hereditary disorders like Thalassaemia, Sideroblasticanemia. Etc.

Duration of study: The period of study was for two months

\section{Assessment criteria:}

- Assessment was analyzed on the basis of improvement in the clinical features.

- The assessment was based on the laboratory investigations conducted before and after treatment. 


\section{Laboratory investigations:}

- Blood: HB\%, TC, DC, ESR, Peripheral smear, Serum ferritin (If needed)

- Stools: Microscopic

- Urine: Routine, microscopic.

\section{Collection of drugs:}

All the drugs of Dhatriloha both herbal and mineral were collected from the SDM pharmacy, Udupi for the pharmaceutical process.

Drugs:

1. Amalakichurna - $100 \mathrm{gms}$

2. Lohabhasma -- 100 gms

3. Haridrachurna -- 100 gms

4. Trikatuchurna -- 33 gms each

5. Amalakikashaya - as per need for bhavana

\section{Method:}

All the above drugs each of 100 gms was taken in a khalva and powdered finely. Then it was triturated with $200 \mathrm{ml}$ of Amalakikashaya for 3 hours for 3days. Then vatis were prepared of pea size and allowed to dry under shade.

\section{Dosage:}

Selected thirty patients were given Dhatriloha compound. The dosage was given as $250 \mathrm{mg}$ twice a day for a period of 2 months.

\section{Grading of the Assessment criteria: Weakness:}

- No weakness - 0

- Weakness not affecting his daily activities - 1

- Weakness affecting his daily activities - 2

- Activities reduced due to weakness -3 .

\section{Fatigue:}

- No Fatigue - 0 .

- Fatigue not affecting his daily activities - 1
- Fatigue affecting his daily activities - 2

- Activities reduced due to weakness -3 .

\section{Exertional Dyspnoea :}

- No Exertional Dyspnoea - 0

- Mild dyspnoea with normal activities - 1

- Dyspnoea stops his daily activities intermittently - 2

- Dyspnoea stops his daily activities frequently - 3

Palpitation:

- No Palpitation - 0.

- Mild Palpitation with normal activities - 1 .

- Palpitation with daily activities - 2

- Palpitation during rest - 3 .

Pallor:

- No Pallor - 0.

- Conjunctiva slightly pale, nail and other mucus membrane not pale - 1

- Conjunctiva pale, nail and other mucus membrane slightly pale -2 .

- Conjunctiva, mucus membrane and nails pale -3

Assessment of the total efficacy of the therapy:

Response of Clinical Manifestations:

1) Marked response: When the relief is partially observed between 75$99.9 \%$ in both signs and symptoms.

2) Moderate response: When the relief is partially observed during the treatment i.e. getting relief in about $50-75 \%$ of both signs and symptoms collectively or individually.

3) Mild response: When the relief is about 25-50 \% in signs and symptoms.

4) Unchanged: In whom there is no relief found.

\section{Laboratory Investigations:}

1) Marked Response : Increase of $\mathrm{Hb} \%$ between $2-3 \mathrm{gm} \%$ 
2) Moderate response : Increase of $\mathrm{Hb} \%$ between $1-2 \mathrm{gm} \%$

3) Mild Response : Increase of $\mathrm{Hb} \%$ between $0-1 \mathrm{gm} \%$

4) Unchanged : : No change in $\mathrm{Hb} \%$ Observations and Results: view of:

Analysis was done from the point of

1. Clinical condition of the patients before and after treatment procedure.

2. Hematological estimation before and after treatment procedure.

Of the 30 patients studied, $66.67 \%$ patients were in 1-3 years age groups, followed by $33.33 \%$ in age group of 4-6 years (Table No.1). $66.67 \%$ patients were Male and 33. $33 \%$ were Females (Table No.2). $36.36 \%$ were of middle class, $54.54 \%$ patients were belonging to poor class of the society and $9.10 \%$ patients were belonging to High class of the society (Table No.3). $70 \%$ patients were Nonvegetarian having, $30 \%$ patients were Vegetarian. (Table No.4)

In a sample size of 30 patients, 10 patients $(33.33 \%)$ were shown marked improvement, 16 patients $(53.33 \%)$ showed moderate improvement, 4 patients (13.33\%) showed mild improvement.
Table 1: Age wise distribution of patients

\begin{tabular}{|c|c|c|}
\hline $\begin{array}{l}\text { Age } \\
\text { years) }\end{array}$ & $\begin{array}{ll}\text { No } & \text { of } \\
\text { patients }\end{array}$ & $\%$ \\
\hline $1-3$ & 22 & 66.67 \\
\hline $4-6$ & 11 & 33.33 \\
\hline
\end{tabular}

Table 2: Sex wise distribution of patients

\begin{tabular}{|l|l|l|}
\hline Sex & $\begin{array}{l}\text { No of } \\
\text { patients }\end{array}$ & $\%$ \\
\hline Male & 22 & 66.67 \\
\hline Female & 11 & 33.33 \\
\hline
\end{tabular}

Table 3: Economic status wise distribution of patients

\begin{tabular}{|l|l|l|}
\hline $\begin{array}{l}\text { Economic } \\
\text { status }\end{array}$ & $\begin{array}{l}\text { No of } \\
\text { patients }\end{array}$ & $\%$ \\
\hline Poor & 18 & 54.54 \\
\hline Middle & 12 & 36.36 \\
\hline Rich & 3 & 9.10 \\
\hline
\end{tabular}

Table 4: Diet wise distribution of patients

\begin{tabular}{|l|l|l|}
\hline Diet & $\begin{array}{l}\text { No of } \\
\text { patients }\end{array}$ & $\%$ \\
\hline Vegetarian & 10 & 30 \\
\hline Mixed & 23 & 70 \\
\hline
\end{tabular}

\section{Results:}

Table 5: Effects of Therapy on Hridrava of 30 patients of Pandu roga:

\begin{tabular}{|l|l|l|l|l|l|l|l|l|}
\hline Symptom & $\mathbf{n}$ & \multicolumn{2}{|l|}{ Mean } & \% & SD & SE & 't' value & 'p' value \\
\cline { 3 - 6 } & & $\mathbf{B T}$ & $\mathbf{A T}$ & & & & & \\
\hline Weakness & 30 & 1.3 & 0.4 & 69.23 & 0.48 & 0.08 & 10.25 & $<0.001$ \\
\hline Fatigue & 30 & 1.166 & 0.4 & 65.71 & 0.430 & 0.07 & 9.76 & $<0.001$ \\
\hline $\begin{array}{l}\text { Exertional } \\
\text { dyspnoea }\end{array}$ & 30 & 0.4 & 0.066 & 83.33 & 0.479 & 0.087 & 3.80 & $<0.001$ \\
\hline Palpitation & 30 & 0.5 & 0.06 & 86.66 & 0.50 & 0.09 & 4.70 & $<0.001$ \\
\hline Pallor & 30 & 1.63 & 0.96 & 40.8 & 0.53 & 0.09 & 6.82 & $<0.001$ \\
\hline Hb \% & 30 & 9.5 & 10.38 & 8.77 & 0.506 & 0.092 & 9.51 & $<0.001$ \\
\hline
\end{tabular}

Table 6: Over All Effect of Therapy

\begin{tabular}{|l|l|l|}
\hline Result & No. of Patients & \% \\
\hline Complete & 0 & 0 \\
\hline Marked & 10 & 33.33 \\
\hline Moderate & 16 & 53.33 \\
\hline Mild & 4 & 13.33 \\
\hline
\end{tabular}




\section{DISCUSSION:}

Out of the 30 patients $33.3 \%$ showed marked improvement, 53.3\% showed moderate and $13.3 \%$ showed mild improvement in their symptoms.

In this series of 30 patients of iron deficiency anemia $33.33 \%$ patients showed marked improvement, $53.33 \%$ patients showed moderate improvement and $13.33 \%$ patients showed mild improvement.

There was considerable decrease in signs and symptoms of iron deficiency anemia after treatment. This improvement can be attributed to property of Dhatriloha and thereby increased the hemoglobin of the body.

Administration of Dhatriloha through the oral route showed no side effects such as colicky pain, gastric distress, constipation, diarrhea, nausea and vomiting.

Overall picture of the results obtained in the study suggests that Dhatriloha increase about one gm/dl of hemoglobin by the two months of the treatment.

\section{Probable Mode of Action of Drug:}

The ingredients of Dhatriloha are as follows:

Amalaki and Loha are main ingredients in this yoga and hence the name Dhatriloha mentioned in Bhaishajya Ratnavali.

Action of the medicine mainly depends upon its constituents like Rasa, Guna, Veerya, Vipaka, Prabhava etc.

Rasa: Amalaki is an Amla rasa pradhana and can increase Raktha and hence in Rakthalpatha, Amla preeti is seen. It also being a rich source of Vit.C helps in absorption of iron. Hence it is used in anemia along with iron compound. Shunti, Marica, Pippali and Haridra are Katu rasa pradhana dravyas which can promote Agni by their Deepana \& Pachana properties which can nullify the
Agnimandhya, Aruchi like laksanas of Pandu roga. They also provide an acidic media for the better absorption of Loha bhasma (Iron).

Guna: Laghu, Ruksha, Snigdha gunas of dravyas can revert back the conditions like Dhatu Shaithilya, Gourava.

Virya: Most of dravyas of yoga have Sheeta Virya.

Vipaka: Most of dravyas have Madhura Vipaka viz; Amalaki, Shunti, Pippali, Loha bhasma. Madhura, Sheeta guna are BalaVarnakara, Dhatuvardhaka, Preenana and Jeevana.

Prabhava: Pramathya property of Marica may help in clearing the Srothoavarodha. Haridra acts as a Krimighna and Loha bhasma can directly increase the Raktha dhatu (Hematinic effect). Amalaki can act as Rasayana to prevent Ojokshaya.

Dosaghnata: All the ingredients of yoga are Tridoshahara and Kapha Vatashamaka. As we know, one among Kaphaja vyadhis is Pandu roga. Vitiated Kapha in Twacha produces Shweta avabhasata and vitiated Vata in the body is responsible for producing laksanas of Pandu roga like Karshya, DhatuKshaya, Shaithilya etc., to nullify the Kapha and Vata these dravyas are very much important.

Hence by considering above points Dhatriloha might have produced beneficial effect in the signs and symptoms of the disease as well as increasing the hemoglobin concentration.

\section{CONCLUSION:}

Dhatriloha is an important drug described in classics which is therapeutically useful.

Dhatriloha is effective in the management of Iron deficiency anemia in children.

Dhatriloha has haematinic effect.

No adverse effects like constipation, gastric irritation etc., by administration of 
Dhatriloha were seen during the period of study.

Dhatriloha can be considered as safest drug than other iron preparations in IDA due to the presence of Dhatri, rich in vitamin $\mathrm{C}$.

For complete cure of IDA, a long term use of Dhatriloha is required.

Finally it can be concluded that Dhatriloha has a positive role in the management of disease Iron Deficiency Anaemia in children.

\section{References:}

1. Srikantha Murthy KR. Bhavamishra's Bhavaprakasha translation. Varanasi; Chowkamba Krishnadas Acadamy; 2004.
2. Tewari PV. Kashyapa Samhitha translation; Varanasi; Chaukamba Visvabharati; 1996

3. Tripathi Indra Deva. Vagbhatta Acharya's Rasa Ratna Samucchaya translation. Delhi; Chaukamba Sanskrit Sanshthan; 2000

4. Ram Karan Sharma, Vaidya Bhagavan Dash. Charaka Samhita translation. Varanasi; Chaukamba Sanskrit Series; 2002

5. Nadakrani AK, Nadkarni KM. Indian Materia Medica Volume I, $2^{\text {nd }}$ Edition. Bombay; Popular Prakashan; 1992

6. Guruprasada, Sharma PV. Dhanvatari Nighantu Translation. $3^{\text {rd }}$ Edition. Varanasi; Chokhambha Orientalia Publication; 2002. 


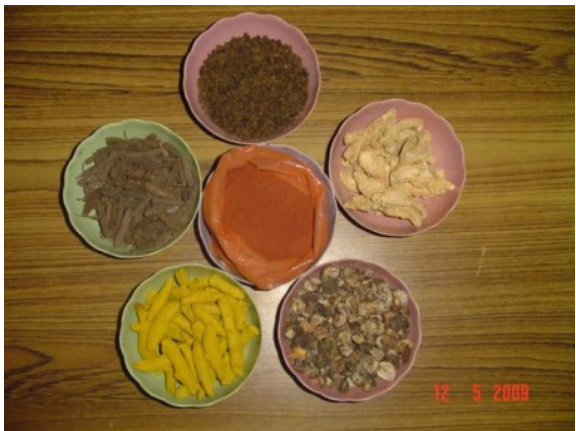

Figure 1: Raw Drugs

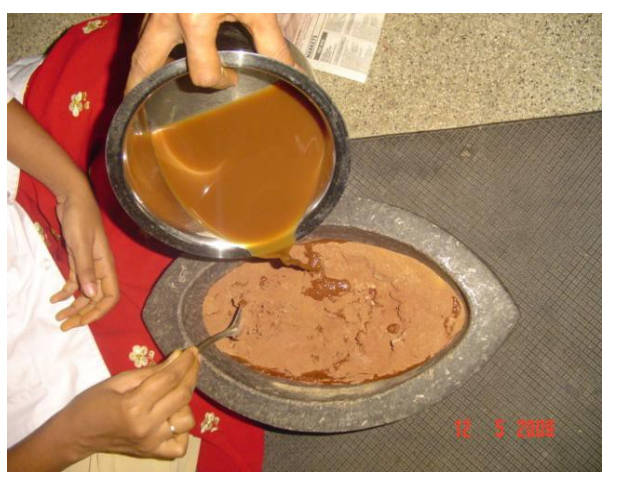

Figure 3: Mixing of the ingredients

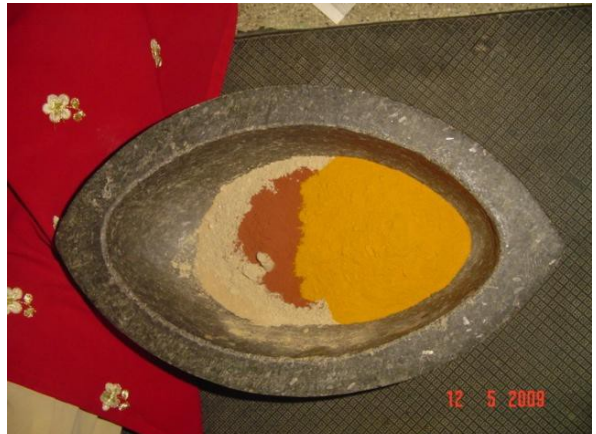

Figure 2: Mixing of the Ingredients

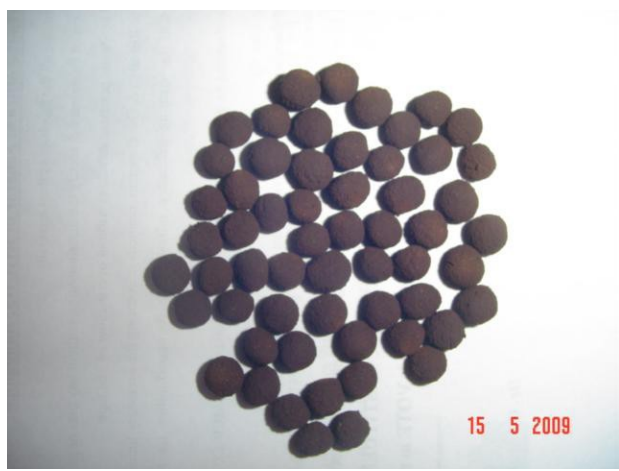

Figure 4: Dhatrilouha pills

$* * * * * *$ 